\title{
PENATALAKSANAAN ULKUS KAKI DIABETES SECARA TERPADU
}

\author{
Yuanita A. Langi \\ Bagian Ilmu Penyakit Dalam Fakultas Kedokteran Universitas Sam Ratulangi Manado \\ Email: meralday@yahoo.co.id
}

\begin{abstract}
A diabetic foot ulcer is a common and fearful chronic complication of diabetes mellitus often resulting in amputation, and even death. A diabetic foot ulcer can be prevented by early screening and education in high risk individuals, and the management of underlying conditions such as neuropathy, peripheral arterial disease, and deformity. The prevalence of diabetic foot ulcer patients is $4-10 \%$ of the general population, with a higher prevalence in elderly people. Around 14-24\% of diabetic foot ulcer patients need amputations with a recurrence rate of $50 \%$ after three years. The main pathogenesis of diabetic foot ulcer is neuropathy and peripheral arterial disease (PAD). PAD contributes to diabetic foot ulcers in $50 \%$ of cases; however, it rarely stands alone. Other factors such as smoking, hypertension, and hyperlipidemia may contribute, too. In addition, PAD reduces the access of oxygen and antibiotics to the ulcers. Management of diabetic foot ulcers includes treatment of ischemia by promoting tissue perfusion, debridement for removing necrotic tissues, wound treatment for creating moist wound healing, off-loading the affected foot, surgery intervention, management of the co-morbidities and infections, and prevention of wound recurrences. Other adjuvant modalities include hyperbaric oxygen treatment, GCSF, growth factors, and bioengineered tissues.
\end{abstract}

Keywords: diabetic ulcer, debridement, off loading

\begin{abstract}
Abstrak: Ulkus kaki diabetes (UKD) merupakan salah satu komplikasi kronik diabetes melitus yang sering dijumpai dan ditakuti oleh karena pengelolaannya sering mengecewakan dan berakhir dengan amputasi, bahkan kematian. UKD dapat dicegah dengan melakukan skrining dini serta edukasi pada kelompok berisiko tinggi, dan penanganan penyebab dasar seperti neuropati, penyakit artei perifer dan deformitas. Prevalensi pasien UKD berkisar 4$10 \%$ dari populasi umumnya, dengan prevalensi yang lebih tinggi pada manula. Sekitar 1424\% pasien UKD memerlukan amputasi dengan rekurensi $50 \%$ setelah tiga tahun. Patogenesis utama UKD yaitu neuropati dan penyakit arteri perifer (PAP). PAP berkontribusi $50 \%$ pada pasien UKD, tetapi hal ini jarang dijumpai tunggal. Terdapat faktor-faktor lain yang turut berperan seperti merokok, hipertensi dan hiperlipidemia. Selain itu PAP menurunkan akses oksigen dan antibiotik ke dalam ulkus. Penatalaksanaan UKD meliputi penanganan iskemia dengan meningkatkan perfusi jaringan, debridemen untuk mengeluarkan jaringan nekrotik, perawatan luka untuk menghasilkan moist wound healing, off-loading kaki yang terkena, intervensi bedah, pananganan komorbiditas dan infeksi, serta pencegahan rekurensi luka. Terapi ajuvan meliputi terapi oksigen hiperbarik, pemberian granulocyte colony stimulating factors (GCSF), growth factors dan bioengineerd tissues.
\end{abstract}

Kata kunci: ulkus diabetes, debridemen, off loading

Ulkus kaki diabetes (UKD) merupakan salah satu komplikasi kronik diabetes melitus (DM) yang sering dijumpai dan ditakuti.
Hal ini disebabkan karena hasil pengelolaan UKD sering mengecewakan baik bagi dokter, pasien maupun keluarganya, serta 
dapat berakhir dengan amputasi bahkan kematian. ${ }^{1}$ Di negara maju, UKD masih merupakan masalah kesehatan yang besar. Dengan adanya perkembangan metode dan teknologi penatalaksanaan UKD serta klinik kaki diabetes maka angka kematian dan amputasi dapat ditekan. ${ }^{1,2}$ Di Indonesia, UKD masih merupakan masalah yang rumit dan tidak terkelola dengan maksimal. Selain itu permasalahan biaya pengelolaan yang besar menambah peliknya masalah kaki diabetes. ${ }^{1}$

Pasien DM memiliki risiko 15\%-25\% dalam hidupnya untuk mengalami kaki diabetes $^{3-7}$ yang pada $40-80 \%$ kasus berkembang menjadi UKD. ${ }^{5}$ Insidens UKD di Amerika Serikat sekitar 3\% tiap tahun, sedangkan di Inggris berkisar $10 \%{ }^{8} \mathrm{DM}$ merupakan penyakit yang paling sering dikaitkan dengan amputasi ekstremitas bagian bawah, dan merupakan penyebab lebih dari $50 \%$ amputasi nontraumatik di Amerika dan Eropa. $3,9,10$

Pada hakekatnya UKD dapat dicegah dengan cara mela-kukan skrining dini serta edukasi penata-laksanaan kaki diabetes pada individu be-risiko tinggi. Demikian pula pencegahan dan pengelolaan yang tepat terhadap faktor-faktor penyebab dasar patogenesis kaki dia-betes, yakni neuropati, penyakit arteri peri-fer dan deformitas dapat mencegah timbul-nya UKD serta segala konsekuensinya. ${ }^{11}$

\section{EPIDEMIOLOGI}

Prevalensi UKD berkisar antara 4$10 \%$, dengan prevalensi yang lebih rendah (1,5-3,5\%) pada orang muda dan lebih tinggi $(5-10 \%)$ pada orang tua. ${ }^{4,10}$ Sekitar $14-24 \%$ pasien UKD akan memerlukan amputasi, dengan angka rekurensi $50 \%$ setelah tiga tahun. ${ }^{6,8,9}$

Kesintasan (survival rate) setelah amputasi ekstremitas bagian bawah pada individu diabetes lebih rendah dibandingkan individu nondiabetes. Mortalitas lima tahun paska amputasi sekitar $68 \%,{ }^{3,8}$ dan angka harapan hidup lebih rendah pada pasien dengan tingkat amputasi yang lebih tinggi. ${ }^{10}$ Di Indonesia angka kematian dan angka amputasi masih tinggi, masingmasing sebesar $16 \%$ dan $25 \%$ (RSUPCM tahun 2003), sebanyak 14,3\% akan meninggal setahun paska amputasi, dan sebanyak $37 \%$ meninggal dalam tiga tahun paska amputasi. ${ }^{1}$

\section{PATOGENESIS}

Patogenesis utama UKD yaitu neuropati, kemudian iskemia pembuluh darah perifer. ${ }^{11}$ Prevalensi neuropati perifer $23-50 \%$ pada pasien $\mathrm{DM}^{4,11,12}$ dan lebih dari $60 \%$ UKD disebabkan neuropati yang berupa neuropati sensorik, motorik dan otonom. ${ }^{8,11,13}$ Hilangnya sensasi nyeri dan suhu akibat neuropati sensorik menyebabkan hilangnya kewaspadaan terhadap trauma atau benda asing, akibatnya banyak luka yang tidak diketahui secara dini dan semakin memburuk karena terus-menerus mengalami penekanan. ${ }^{11,12,14}$ Kerusakan inervasi otot-otot intrinsik kaki akibat neuropati motorik menyebabkan ketidakseimbangan antara fleksi dan ekstensi kaki serta deformitas kaki, yang kemudian menyebabkan terjadinya perubahan distribusi tekanan pada telapak kaki yang selanjutnya memicu timbulnya kalus. Kalus yang tidak dikelola dengan baik akan menjadi sumber trauma bagi kaki tersebut. ${ }^{1,11,15}$ Neuropati otonom menyebabkan penurunan fungsi kelenjar keringat dan sebum. Kaki akan kehilangan kemampuan alami untuk melembabkan kulit, kulit menjadi kering dan pecah-pecah sehingga mudah terinfeksi. ${ }^{11,13,15}$

Penyakit arteri perifer (PAP) merupakan faktor yang berkontribusi terhadap perkembangan UKD pada 50\% kasus. PAP jarang berdiri sendiri sebagai penyebab UKD. ${ }^{7,10,11,13,15}$ Merokok, hipertensi dan hiperlipidemia memberikan kontribusi pada perkembangan PAP. Adanya iskemia akibat insufisiensi arteri perifer menyebabkan terjadinya penurunan oksigenasi di daerah ulkus yang mempersulit penyembuhan. Selain itu PAP juga menyebabkan sulitnya pengaliran antibiotik ke daerah infeksi. $^{2,5,10,15}$ 


\section{PRINSIP PENATALAKSANAAN UL- KUS KAKI DIABETES}

Tujuan utama pengelolaan UKD yaitu untuk mengakses proses kearah penyembuhan luka secepat mungkin karena perbaikan dari ulkus kaki dapat menurunkan kemungkinan terjadinya amputasi dan kematian pasien diabetes. Secara umum pengelolaan UKD meliputi penanganan iskemia, debridemen, penanganan luka, menurunkan tekanan plantar pedis (off-loading), penanganan bedah, penanganan komorbiditas dan menurunkan risiko kekambuhan serta pengelolaan infeksi. ${ }^{10,16}$

\section{Penanganan iskemia}

Perfusi arteri merupakan hal penting dalam proses penyembuhan dan harus dinilai awal pada pasien UKD. Penilaian kompetensi vaskular pedis pada UKD seringkali memerlukan bantuan pemeriksaan penunjang seperti MRI angiogram, doppler maupun angiografi. Pemeriksaan sederhana seperti perabaan pulsasi arteri poplitea, tibialis posterior dan dorsalis pedis dapat dilakukan pada kasus UKD kecil yang tidak disertai edema ataupun selulitis yang luas. Ulkus atau gangren kaki tidak akan sembuh bahkan dapat menyerang tempat lain di kemudian hari bila penyempitan pembuluh darah kaki tidak diatasi. ${ }^{1,11,17}$

Bila pemeriksaan kompetensi vaskular menunjukkan adanya penyumbatan, bedah vaskular rekonstruktif dapat meningkatkan prognosis dan selayaknya diperlukan sebelum dilakukan debridemen luas atau amputasi parsial. Beberapa tindakan bedah vaskular yang dapat dilakukan antara lain angioplasti transluminal perkutaneus (ATP), tromboarterektomi dan bedah pintas terbuka (by pass) ${ }^{14,18}$ Berdasarkan penelitian, revaskularisasi agresif pada tungkai yang mengalami iskemia dapat menghindarkan amputasi dalam periode tiga tahun sebesar 98\%. Bedah bypass dilaporkan efektif untuk jangka panjang. Kesintasan (survival rate) dari ekstremitas bawah dalam 10 tahun pada mereka yang memakai prosedur bedah bypass lebih dari $90 \% .{ }^{15}$ Penggunaan antiplatelet ditujukan terhadap keadaan insufisiensi arteri perifer untuk memperlambat progresifitas sumbatan dan kebutuhan rekonstruksi pembuluh darah. $^{11}$

\section{Debridemen}

Debridemen merupakan upaya untuk membersihkan semua jaringan nekrotik, karena luka tidak akan sembuh bila masih terdapat jaringan nonviable, debris dan fistula. Tindakan debridemen juga dapat menghilangkan koloni bakteri pada luka. ${ }^{10,15}$ Saat ini terdapat beberapa jenis debridemen yaitu autolitik, enzimatik, mekanik, biologik dan tajam. ${ }^{10}$

Debridemen dilakukan terhadap semua jaringan lunak dan tulang yang nonviable. Tujuan debridemen yaitu untuk mengevakuasi jaringan yang terkontaminasi bakteri, mengangkat jaringan nekrotik sehingga dapat mempercepat penyembuhan, menghilangkan jaringan kalus serta mengurangi risiko infeksi lokal. ${ }^{16}$ Debridemen yang teratur dan dilakukan secara terjadwal akan memelihara ulkus tetap bersih dan merangsang terbentuknya jaringan granulasi sehat sehingga dapat mempercepat proses penyembuhan ulkus. ${ }^{6,19}$

\section{Perawatan luka}

Prinsip perawatan luka yaitu menciptakan lingkungan moist wound healing atau menjaga agar luka senantiasa dalam keadaan lembab. ${ }^{6,10,11}$ Bila ulkus memroduksi sekret banyak maka untuk pembalut (dressing) digunakan yang bersifat absorben. Sebaliknya bila ulkus kering maka digunakan pembalut yang mampu melembabkan ulkus. Bila ulkus cukup lembab, maka dipilih pembalut ulkus yang dapat mempertahankan kelembaban. ${ }_{1,6,15}$

Disamping bertujuan untuk menjaga kelembaban, penggunaan pembalut juga selayaknya mempertimbangkan ukuran, kedalaman dan lokasi ulkus. ${ }^{15}$ Untuk pembalut ulkus dapat digunakan pembalut konvensional yaitu kasa steril yang dilembabkan dengan $\mathrm{NaCl} 0,9 \%$ maupun pembalut modern yang tersedia saat ini. Beberapa jenis pembalut modern yang sering dipakai 
dalam perawatan luka, seperti: hydrocolloid, hydrogel, calcium alginate, foam dan sebagainya. Pemilihan pembalut yang akan digunakan hendaknya senantiasa mempertimbangkan cost effective dan kemampuan ekonomi pasien. ${ }^{1,10}$

\section{Menurunkan tekanan pada plantar pe- dis (off-loading)}

Tindakan off-loading merupakan salah satu prinsip utama dalam penatalaksanaan ulkus kronik dengan dasar neuropati. Tindakan ini bertujuan untuk mengurangi tekanan pada telapak kaki. ${ }^{1,16}$ Tindakan offloading dapat dilakukan secara parsial maupun total. Mengurangi tekanan pada ulkus neuropati dapat mengurangi trauma dan mempercepat proses penyembuhan luka. ${ }^{6,10,16}$ Kaki yang mengalami ulkus harus sedapat mungkin dibebaskan dari penekanan. Sepatu pasien harus dimodifikasi sesuai dengan bentuk kaki dan lokasi ulkus. ${ }^{6}$ Metode yang dipilih untuk off-loading tergantung dari karakteristik fisik pasien, lokasi luka, derajat keparahan dan ketaatan pasien. ${ }^{10}$ Beberapa metode off loading antara lain: total non-weight bearing, total contact cast, foot cast dan boots, sepatu yang dimodifikasi (half shoe, wedge shoe), serta alat penyanggah tubuh seperti cruthes dan walker. $1,10,15$

\section{Penanganan bedah}

Jenis tindakan bedah tergantung dari berat ringannya UKD. Tindakan elektif ditujukan untuk menghilangkan nyeri akibat deformitas seperti pada kelainan spur tulang, hammertoes atau bunions. Tindakan bedah profilaktif diindikasikan untuk mencegah terjadinya ulkus atau ulkus berulang pada pasien yang mengalami neuropati dengan melakukan koreksi deformitas sendi, tulang atau tendon. Bedah kuratif diindikasikan bila ulkus tidak sembuh dengan perawatan konservatif, misalnya angioplasti atau bedah vaskular. Osteomielitis kronis merupakan indikasi bedah kuratif. ${ }^{10}$ Bedah emergensi adalah tindakan yang paling sering dilakukan, dan diindikasikan untuk menghambat atau menghentikan proses in- feksi, misalnya ulkus dengan daerah infeksi yang luas atau adanya gangren gas. Tindakan bedah emergensi dapat berupa amputasi atau debridemen jaringan nekrotik. ${ }^{10,20}$

\section{Penanganan komorbiditas}

Diabetes merupakan penyakit sistemik multiorgan sehingga komorbiditas lain harus dinilai dan dikelola melalui pendekatan tim multidisiplin untuk mendapatkan hasil yang optimal. Komplikasi kronik lain baik mikro maupun makroangiopati yang menyertai harus diidentifikasi dan dikelola secara holistik. Kepatuhan pasien juga merupakan hal yang penting dalam menentukan hasil pengobatan. ${ }^{10}$

\section{Mencegah kambuhnya ulkus}

Pencegahan dianggap sebagai elemen kunci dalam menghindari amputasi kaki. Pasien diajarkan untuk memperhatikan kebersihan kaki, memeriksa kaki setiap hari, menggunakan alas kaki yang tepat, mengobati segera jika terdapat luka, pemeriksaan rutin ke podiatri, termasuk debridemen pada kapalan dan kuku kaki yang tumbuh ke dalam. Sepatu dengan sol yang mengurangi tekanan kaki dan kotak yang melindungi kaki berisiko tinggi merupakan elemen penting dari program pencegahan. ${ }^{2}$

\section{Pengelolaan infeksi}

Infeksi pada UKD merupakan faktor pemberat yang turut menentukan derajat agresifitas tindakan yang diperlukan dalam pengelolaan UKD. Dilain pihak infeksi pada UKD mempunyai permasalahan sendiri dengan adanya berbagai risiko seperti status lokalis maupun sistemik yang imunocompromised pada pasien DM, resistensi mikroba terhadap antibiotik, dan jenis mikroba yang adakalanya memerlukan antibiotik spesifik yang mahal dan berkepanjangan. Dasar utama pemilihan antibiotik dalam penatalaksanaa UKD yaitu berdasarkan hasil kultur sekret dan sensitivitas sel. Cara pengambilan dan penanganan sampel berpengaruh besar terhadap ketepatan hasil kultur kuman. Telah dilaporkan bahwa ter- 
dapat perbedaan jenis kuman yang didapat pada bahan sekret yang diambil superfisial dengan yang deep swab.

Sambil menunggu hasil kultur, pada UKD yang terinfeksi penggunaan antibiotik dapat dipilih secara empirik. Terdapat berbagai klasifikasi pengelolaan kaki diabetes mulai dari yang sederhana sampai kompleks yang mencantumkan tuntunan penggunaan antibiotika. Beberapa klasifikasi tersebut yaitu klasifikasi Wagner, The University of Texas classification, klasifikasi PEDIS oleh International Consensus on the Diabetic Foot, dan klasifikasi berdasarkan derajat keparahan oleh Infectious Disease Society of America (IDSA). ${ }^{6,21,22}$

Secara klinis, infeksi yang tidak mengancam tungkai biasanya terlihat sebagai ulserasi yang dangkal, tanpa iskemia yang nyata, tidak mengenai tulang atau sendi, dan area selulitis tidak lebih dari $2 \mathrm{~cm}$ dari pusat ulkus. Pasien tampak stabil serta tidak memperlihatkan tanda dan gejala infeksi sistemik. Pengelolaan pasien dilakukan sebagai pasien rawat jalan. Perawatan di rumah sakit hanya bila tidak ada perbaikan setelah 48-72 jam atau kondisi memburuk. ${ }^{6}$ Antibiotik langsung diberikan disertai pembersihan dan debridemen ulkus. Penanganan ulkus ini selanjutnya seperti yang diuraikan sebelumnya, koreksi hiperglikemia dan kontrol komorbid lainnya. Respon terhadap pengobatan dievaluasi setelah 4872 jam untuk menilai tindakan yang mungkin perlu dilakukan. ${ }^{6,10,12}$ Aspek pencegahan, pendidikan pasien, perawatan dan penanganan ortotik juga dilakukan secara terpadu. ${ }^{12}$

Infeksi disebut mengancam bila UKD berupa ulkus yang dalam sampai mengenai tulang dengan selulitis yang lebih dari $2 \mathrm{~cm}$ dan/atau disertai gambaran klinis infeksi sistemik berupa demam, edema, limfangitis, hiperglikemia, leukositosis dan iskemia. Perlu diperhatikan, tidak semua pasien diabetes dengan infeksi yang relatif berat akan menunjukkan tanda dan gejala sistemik seperti tersebut diatas. Jika ulkus mencapai tulang atau sendi, kemungkinan besar akan terjadi osteomielitis. ${ }^{10,23}$

Pasien dengan infeksi yang mengancam ekstremitas harus dirawat di rumah sa- kit untuk manajemen yang tepat. Debridemen dilakukan sejak awal dengan tetap memperhitungkan ada/tidaknya kompetensi vaskular tungkai. Jaringan yang diambil dari luka dikirim untuk kultur. Tindakan ini mungkin perlu dilakukan berulang untuk mengendalikan infeksi. ${ }^{23}$ Terapi empiris untuk infeksi berat harus berspektrum luas dan diberikan secara intravena dengan mempertimbangkan faktor lain seperti biaya, toleransi pasien, alergi, potensi efek yang merugikan ginjal atau hati, kemudahan pemberian dan pola resistensi antibiotik setempat. $^{5,18}$ Infeksi kronik dan berat yang mengancam tungkai umumnya disebabkan oleh infeksi polimikroba yang mencakup organisme aerob gram positif dan negatif serta anaerob. ${ }^{2,5,15,23}$ Pseudomonas sering diperoleh dari isolasi luka yang menggunakan pembalutan basah; enterokokus umumnya dibiakkan dari pasien yang sebelumnya telah diterapi sefalosporin; kuman anaerob sering ditemukan pada luka dengan keterlibatan jaringan yang dalam dan nekrosis; dan methicillin-resistant Staphylococcy aureus (MRSA) sering diperoleh pada pasien yang sebelumnya pernah di rawat inap atau diberikan terapi antibiotika. ${ }^{5,12,20,22}$ Bila terjadi infeksi berulang meskipun terapi antibiotik tetap diberikan, perlu dilakukan kultur ulang jaringan untuk menyingkirkan infeksi superimposed. ${ }^{10,22}$

Lamanya pemberian antibiotik tergantung pada gejala klinis, luas dan dalamnya jaringan yang terkena serta beratnya infeksi. ${ }^{20,22}$ Pada infeksi ringan sampai sedang antibiotik dapat diberikan 1-2 minggu, sedangkan pada infeksi yang lebih berat antibiotik diberikan 2-4 minggu. Debridemen yang adekuat, reseksi atau amputasi jaringan nekrosis dapat mempersingkat waktu pemberian antibiotik. ${ }^{2,5,22}$ Pada kasus osteomielitis, jika tulang terinfeksi tidak dievakuasi, maka antibiotik harus diberikan selama 6-8 minggu, bahkan beberapa literatur menganjurkan sampai 6 bulan. ${ }^{10,16}$ Jika semua tulang yang terinfeksi dievakuasi, antibiotik dapat diberikan lebih singkat, yaitu 1-2 minggu dan ditujukan untuk infeksi jaringan lunak. ${ }^{5,10}$

Efektivitas terapi dievaluasi dengan 
beberapa parameter, antara lain respon klinis pasien, suhu, leukosit dan hitung jenis, laju endap darah dan penanda inflamasi lainnya, kontrol gula darah dan parameter metabolik, serta tanda-tanda penyembuhan luka dan peradangan. Pada keadaan kompetensi vaskular yang baik, pengukuran suhu kaki merupakan parameter klinis inflamasi yang dapat dipegang. Jika terdapat iskemi jaringan luka, antibiotik mungkin tidak dapat mencapai lokasi yang terinfeksi. Oleh karena itu, prosedur rekonstruksi vaskular mungkin harus dilakukan untuk meningkatkan aliran darah ke jaringan yang terinfeksi. ${ }^{5,10}$

\section{TERAPI LAIN}

Terapi ajuvan yang sering digunakan dalam pengelolaan UKD ialah terapi oksigen hiperbarik (TOH). TOH merupakan pemberian oksigen untuk pasien dengan tekanan yang lebih tinggi dari tekanan atmosfer normal. Hal ini menyebabkan peningkatan konsentrasi oksigen dalam darah dan peningkatan kapasitas difusi jaringan. Tekanan parsial oksigen dalam jaringan yang meningkat akan merangsang neovaskularisasi dan replikasi fibroblas serta meningkatkan fagositosis dan leucocyte-mediated killing dari bakteri. ${ }^{10,15,24}$ Indikasi pemberian TOH yaitu UKD yang memenuhi kriteria luka derajat 3 dalam klasifikasi Wagner dan luka yang gagal sembuh setelah 30 hari pengobatan standar, dan terutama ditujukan pada ulkus kronis dengan iskemia. ${ }^{15,24}$

Penggunaan granulocyte colony stimulating factors (GCSF) merupakan terapi alternatif yang masih dalam penelitian. GSCF diketahui dapat meningkatkan aktivitas neutrofil pada pasien DM. ${ }^{18}$ Pemberian suntikan GSCF subkutan selama satu minggu pada UKD yang disertai infeksi terbukti mempercepat eradikasi kuman, memperpendek waktu pemberian antibiotik serta menurunkan angka amputasi. ${ }^{4,18}$

Terapi ajuvan lain dalam pengelolaan UKD yang masih dalam tahap penelitan yaitu penggunaan faktor pertumbuhan (growth factor therapy) dan bioengineered tissue. Platelet-derived growth factor becaplermin (PDGF-b, becaplermin) digunakan untuk merangsang penyembuhan luka dan dianjurkan pada neuropati kaki diabetes. Pemakaian bahan ini secara topikal dikatakan efektif dan aman, namun belum terdapat data yang memadai. ${ }^{4}$ Produk bioengineered tissue seperti bioengineered skin (Apligraf) dan human dermis (Dermagraf) merupakan implan biologik aktif untuk mempercepat penyembuhan ulkus kronik. Produk bioengineered ini bekerja pada sistem penghantaran growth factor dan komponen matriks dermal melalui aktifitas fibroblas yang merangsang pertumbuhan jaringan dan penutupan luka. ${ }^{10,18,23}$

\section{SIMPULAN}

Patogenesis utama UKD yaitu neuropati dan iskemia tungkai. Pengeloaan UKD hendaknya dilakukan melalui pendekatan patofisiologi. Prinsip pengelolaan UKD secara terpadu ialah adekuasi penanganan iskemia, debridemen, penanganan luka, offloading, penanganan bedah, penanganan komorbiditas, menurunkan resiko kekambuhan dan penanganan infeksi. Pengelolaan UKD terinfeksi terbagi atas infeksi yang tidak mengancam tungkai dan yang mengancam tungkai. Pemilihan antibiotik sesuai dengan hasil uji kultur dan sensitivitas, sedangkan lamanya pemberian tergantung pada keadaan klinis dan beratnya infeksi. Terapi ajuvan lain yang dikembangkan dalam pengelolaan UKD antara lain terapi oksigen hiperbarik, pemberian granulocyte colony stimulating factors dan faktor pertumbuhan, serta bioengineered tissue.

\section{DAFTAR PUSTAKA}

1. Waspadji S. Kaki diabetes. Dalam: Sudayo AW, Setiyohadi B, Alwi I, Simadibrata MK, Setiati S, editor. Buku Ajar Ilmu Penyakit Dalam (Edisi V Jilid III). Jakarta: Internal Publishing, 2009; p 19617.

2. Amstrong DG, Lavery AL. Diabetic foot ulcer: prevention, diagnosis and classification. Am Fam Physician. 1998;5(6):1325-32. 
3. Reiber GE, LeMasster JW. Epidemiology and economic impact of foot ulcers and amputations in people with diabetes. In: Browker JH, Pfeifer MA, editors. Levin and O'Neal's The Diabetic Foot (Seventh Edition). Philadelphia: Mosby Elsevier, 2008; p. 3-22.

4. Katsilambors N, Dounis E, Tsapogas P, Tentolouris $\mathbf{N}$. Atlas of the Diabetic Foot. London: John Willey and sons LTD, 2003.

5. Lipsky BA. Infectious problems of the foot in diabetic patients. In: Browker $\mathrm{JH}$, Pfeifer MA, editors. Levin and O'Neal's The Diabetic Foot (Seventh Edition). Philadelphia: Mosby Elsevier, 2008; p. 305-18.

6. American Diabetes Association. Consensus Development Conference on Diabetic Foot Wound Care. Diabetes Care. 1999; 22(8):1354-60.

7. Boulton AJ. The diabetic foot: from art to science. The 18th Camillo Golgi lecture. Diabetologia 2004; 47:1343-53.

8. Reiber GE, Vileikyte L, Boyko EJ, del Aguila M, Smith DG, Lavery LA, et al. Causal pathways for incident lower extremity ulcers in patients with diabetes from two settings. Diabetes Care. 1999; 22:157-62.

9. Boulton AJ, Vileikyte L, RagnarsonTennvall G, Apelqvist J. The global burden of diabetic foot disease. Lancet. 2005;366:1719-24.

10. Frykberg RG, Amstrong DG, Giurini JM, Zgonis T, Driver VR, Kravitz SR, et al. Diabetic foot disorders a clinical practice guidelines. The Journal of Foot and Ankle Surgery. 2000;35(5):S2-59.

11. Bowering CCK. Diabetic foot ulcers pathophysiology, assessment and therapy. Canadian Family Phycisian. 2001;47:1007-16.

12. Bader MS. Diabetic foot infection. American Family Physicians. 2008;78(1):71-9.

13. Conway KP, Harding KG. Wound healing in the diabetic foot. In: Browker $\mathrm{JH}$, Pfeifer MA, editors. Levin and O'Neal's
The Diabetic Foot (Seventh Edition). Philadelphia: Mosby Elsevier, 2008; p. 319-28.

14. Jeffcoate WJ, Hading KG. Diabetic foot ulcers. Lancet. 2003;261:1545-51.

15. Clayton W, Elasi TA. A review of pathophysiology, classification and treatment of foot ulcers in diabetic patients. Clinical Diabetes. 2009;27(2):52-8.

16. Munro N, Rich N, McIntosh C, Foster AVM, Edmonds ME. Infections in the diabetic foot: a practical management guide to foot care. British Journal of Diabetes \& Vascular Disease. 2003;3:1326.

17. Boike AM, Hall JO. A practical guide for examining and treating the diabetic foot. Cleveland Clinic Journal of Medicine. 2002;69(4):342-8.

18. Schaper NC, Prompers LM, Huijoeberts MSP. Treatment of diabetic ulcers. Immun Endoc \& Metab Agents in Med Chem. 2007; 7: 95-104.

19. Cavanagh PR, Lipsky BA, Bradbury AW, Botek G. Treatment for diabetic foot ulcers. Lancet. 2005;366: 1725-33.

20. Edmonds ME, Foster EVM, Sanders LF. A Practical Manual of Diabetic Foot Care. London: Blackwell Publishing, 2004.

21. Brodsky JW. Classification of foot lesions in diabetic Patients. In: Browker JH, Pfeifer MA, editors. Levin and O'Neal's The Diabetic Foot (Seventh Edition). Philadelphia: Mosby Elsevier, 2008; p. 221-6.

22. Lipsky BA, Berendt AR, Deery HG, Embil JM, Joseph WS, Karchmer AW, et al. Diagnosis and treatment of diabetic foot infections. Clinical Infectious Disease. 2004;39:885-910

23. Frykberg RG. Diabetic foot ulcers: pathogenesis and management. Am Fam Physician. 2002;66:1655-62.

24. Stone JA, Cianci $\mathbf{P}$. The adjunctive hyperbaric oxygen therapy in the treatment of lower extremity wounds in patients with diabetes. Diabetes Spectrum. 1997;10(2):118-23. 